\title{
Economic dependence of mountain communities on Chinese caterpillar fungus Ophiocordyceps sinensis (yarsagumba): a case from western Nepal
}

\author{
Uttam Babu Shrestha, Krishna Ram Dhital and Ambika Prasad Gautam
}

\begin{abstract}
Products obtained from forests or other natural environments play a crucial role in sustaining the livelihoods of poor people in developing countries through income generation and the creation of employment opportunities. Although studies have been carried out to evaluate the dependence of local livelihoods on environmental products, quantify the linkage between poverty and biodiversity, and assess the impacts of resource depletion on household economics, most have been focused geographically on the tropics. Our study was conducted in the mountain village of Jumla, Nepal, to quantify the economic contribution of Chinese caterpillar fungus Ophiocordyceps sinensis (yarsagumba) to local households. Income from yarsagumba accounted for up to $65 \%$ of the total household cash income, on average, and its contribution was highest in the poorest households. It contributed to reducing income inequality by $38 \%$, and the income was utilized to purchase food and clothes, celebrate festivals, pay for medical treatment and children's education, and for savings. There was a mean annual decline of 25 pieces in the per capita harvest of yarsagumba during 2010-2014. However, the decline had no adverse impact on household income, as the price increased.
\end{abstract}

Keywords Economic impact, Himalaya, mountain livelihood, Nepal, non-timber forest products, Ophiocordyceps sinensis, yarsagumba

\section{Introduction}

D nvironmental resources, including forest resources, play a key role in rural livelihoods: they supply a wide variety of raw materials for consumption, and provide cash income (Pouliot \& Treue, 2013). Globally, and particularly in developing countries, c. 1.3 billion people rely on environmental products for subsistence livelihoods and monetary income (World Bank, 2004; Vedeld et al., 2007; Angelsen et al., 2014). Both timber and non-timber forest products

UtTAM BABU SHREstha (Corresponding author) Institute for Agriculture and the Environment, University of Southern Queensland, Toowoomba, QLD, 4350, Australia. E-mail ubshrestha@yahoo.com

Krishna Ram Dhital and Ambika Prasad Gautam Kathmandu Forestry College, Kathmandu, Nepal

Received 19 December 2016. Revision requested 8 March 2017

Accepted 31 March 2017. First published online 26 July 2017. provide direct benefits, such as fuelwood for cooking, medicinal plants for health care, fodder for animals, building materials for construction, and wild fruits, fish and bushmeat for consumption (Saha \& Sundriyal, 2012). Forest products also provide rural people with an economic buffer in times of adversity (e.g. sudden changes in economic or social circumstances) (Shackleton \& Shackleton, 2004). In some areas, households generate a substantial amount of income by harvesting and selling forest products, and the contribution of forest products to the total household income exceeds that of agricultural products (Mamo et al., 2007). A meta-analysis of 51 case studies from 17 developing countries showed that environmental income (i.e. income derived from the harvesting of environmental resources provided through natural processes) contributed $20-25 \%$ of the household income of rural people (Vedeld et al., 2007; Pouliot \& Treue, 2013). Likewise, in a global analysis of 8 ,ooo households in 24 developing countries, environmental income (of which $77 \%$ was derived from natural forests) accounted for $28 \%$ of total household income (Angelsen et al., 2014). Non-forest environmental income also plays a substantial role in the livelihoods of rural people; for example, small-scale river fisheries in the Democratic Republic of Congo contribute up to $98 \%$ of the fishers' household income (Béné et al., 2009).

Traditionally, the livelihoods of mountain communities in the Himalaya have been heavily dependent upon natural resources. The major livelihood strategies are subsistence farming, animal husbandry, and collection and trade of medicinal plants (Olsen \& Larsen, 2003). The high-value, low-volume Chinese caterpillar fungus Ophiocordyceps sinensis, known locally as yarsagumba (adopted from yartsa gunbu in Tibetan), is one of several important medicinal species harvested by local communities in mountainous parts of India (Kuniyal \& Sundriyal, 2013), Nepal (Shrestha \& Bawa, 2014a), Bhutan (Wangchuk et al., 2012) and China (Woodhouse et al., 2014). Yarsagumba plays a prominent role in the socio-economy of rural people in the Himalayan region (Shrestha et al., 2014; Pant et al., 2017). A localized study conducted in the Nubri and Tsum valleys of Nepal found that income from yarsagumba accounted for $77-92 \%$ of the total cash income of households (Childs \& Choedup, 2014). Likewise, in Dolpa, Nepal, yarsagumba accounted for up to $72 \%$ of total income for the poorest households (Shrestha \& Bawa, 2014a). Yarsagumba also plays an important role in 
Nepal's national economy. The trade in yarsagumba in Nepal was worth an estimated USD 4.7 million in 2014, based on the revenue records from 11 districts (NRB, 2015). Furthermore, yarsagumba contributes c. $41 \%$ of total revenue collected from the non-timber forest products sector and provides a financial resource to fund social welfare activities such as electrification of villages and maintenance of local schools (Thapa et al., 2014). Occurring in resource-scarce regions, and collected mainly by poor local people, yarsagumba can lift people out of poverty and reduce inequality. However, an understanding of the linkages between income from yarsagumba and income inequality and poverty has been lacking in previous studies (Childs \& Choedup, 2014; Shrestha \& Bawa, 2014a).

Conservation of biodiversity, including forests and other natural ecosystems, and poverty alleviation have become central issues in global policies such as the Convention on Biological Diversity, the Millennium Development Goals (Sachs et al., 2009) and the Sustainable Development Goals. Some argue that biodiversity conservation can alleviate poverty (Walelign et al., 2016), provide employment opportunities for poor and disadvantaged groups, and improve the overall well-being of local people (Turner et al., 2012; Shackleton \& Pandey, 2014). However, there is a lack of empirical evidence linking biodiversity conservation and poverty alleviation (Sunderlin et al., 2005; Roe, 2010). Furthermore, most of the literature related to biodiversity-poverty linkages is focused mainly on non-timber forest products, and ecological settings such as mountains, deserts and artificial exotic habitats have been poorly studied (Vedeld et al., 2007; Roe, 2010; Roe et al., 2015).

Environmental income, including income from forest products, is rarely acknowledged by developing country policy makers in poverty reduction strategies (Oksanen \& Mersmann, 2003; Wunder et al., 2014). However, Nepal's Poverty Reduction Strategy Paper acknowledges the importance of the forestry sector in poverty reduction (Nepal National Planning Commission, 2003). According to a 2015 survey of Nepalese households c. $69 \%$ of employed people $>15$ years old (and up to $76 \%$ in rural areas) were engaged in agriculture, forestry and fishing for their livelihoods (CBS, 2015). In $2004 \mathrm{Nepal}$ introduced a policy to reduce poverty through sustainable management of nontimber forest products (GoN, 2004) but regulations to implement the policy have yet to be formulated (Heinen \& Shrestha-Acharya, 2011). Additionally, there are geographical biases in the government's programmes for forest conservation and livelihood enhancement, with most programmes concentrated in the Terai, Siwalik and mid hills, despite the fact that the mean income from forest resources is higher in mountain areas than in these other areas (Meilby et al., 2014). Furthermore, the government is reluctant to hand over ownership of forests and rangelands in mountainous areas, where high-value environmental resources, including yarsagumba, are found, to local forest user groups (Heinen \& Shrestha-Acharya, 2011).

To design effective development and conservation strategies it is essential to quantify the relative and absolute contributions of environmental income to household income, and understand the determinants of poverty and inequality, and the implications of degradation of natural resources on the household economy (Angelsen \& Wunder, 2003; Oksanen \& Mersmann, 2003; Vedeld, 2004; Angelsen et al., 2014). In some instances, promoting sustainable use of non-timber forest products through formalization of trade can have unintended consequences, such as elite capture, distributional inequity, and exclusion of marginalized communities from the trade (Wynberg et al., 2015).

Here we consider the case of yarsagumba, a resource collected in open-access alpine pastures by mountain communities living in acute poverty. Despite the significant contribution of yarsagumba to the livelihoods of poor people, its potential role in poverty reduction is yet to be formalized by national policy in Nepal (DPR, 2014). Our study was guided by three research questions: (1) What is the contribution of yarsagumba to the local household economy? (2) What are the trends in yarsagumba harvesting and their relationship with income? (3) Does income from yarsagumba correlate with household wealth and income inequality?

\section{Chinese caterpillar fungus (yarsagumba)}

The Chinese caterpillar fungus is an endoparasitic complex formed by the parasitic fungus Ophiocordyceps sinensis and its host caterpillar of Thitarodes moth species (Winkler, 2009). It occurs in the alpine and subalpine grasslands of the Himalaya and the Tibetan Plateau, at 3,000-5,200 m (Shrestha \& Bawa, 2013). Yarsagumba is used traditionally as a medicinal herb to strengthen lungs and kidneys, increase energy and vitality, stop haemorrhaging, decrease phlegm and treat fatigue, and more recently as an aphrodisiac and a tonic known as Himalayan viagra (Zhou et al., 2009). It is one of the most expensive medicinal herbs in the world, with a current market price of USD 128,000 per kg in China (Agency, 2016). Yarsagumba is harvested and sold by hundreds of thousands of poor people in Nepal, China, Bhutan and India. In Nepal, large-scale collection involving tens of thousands of harvesters began after the ban on collection and trade of yarsagumba was lifted in 2001 (Shrestha \& Bawa, 2013). Yarsagumba harvesting is one of the key income sources for poor mountain communities in Nepal, where the availability of other livelihood opportunities is comparatively low (Shrestha \& Bawa, 2014a).

\section{Study area}

This study was carried out in Garjyangkot Village Development Committee of Jumla district, in Nepal 


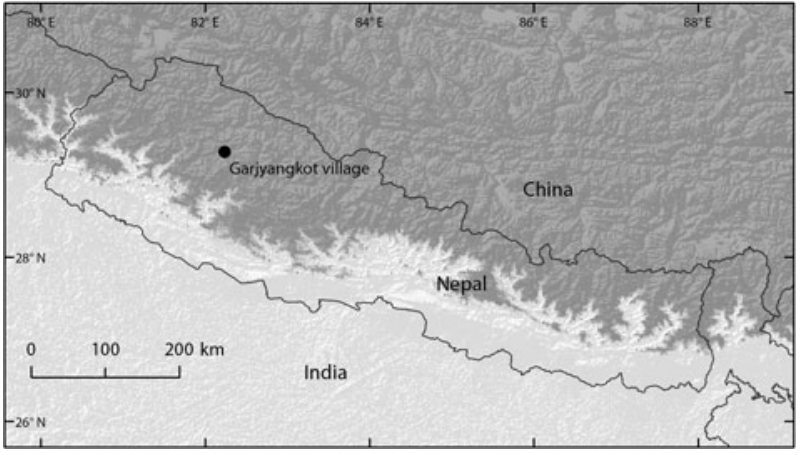

FIG. 1 Location of Garjyangkot village, Jumla district, Nepal.

(Fig. 1). Jumla is one of 27 northern districts from which yarsagumba is reported, and is regarded as one of the top three yarsagumba-producing districts, after Dolpa and Darchula, contributing nearly $7 \%$ of the country's total supply (DFO, 2014). The potential annual production of yarsagumba in Jumla is c. $201 \mathrm{~kg}(\mathrm{GoN}, 2015)$, and $25 \%$ of the total volume collected comes from Garjyangkot Village Development Committee.

Jumla is a remote district, with an area of $2,531 \mathrm{~km}^{2}$ and a total population of 107,395 (GoN, 2015). The per capita income (purchasing power parity) in Jumla is USD 1,007, compared to the national mean of USD 1,160 (Sharma et al., 2014). The district is comparatively dry and receives mean annual rainfall of $740 \mathrm{~mm}$, with alpine and subalpine pastures that cover $>80 \%$ of its land area $(\mathrm{GoN}, 2015)$ and are suitable habitat for yarsagumba. The people of Garjyangkot rely on subsistence farming, animal husbandry, wages derived from seasonal labour in India, and collection of non-timber forest products, and yarsagumba harvesting has become a predominant livelihood strategy in the area.

\section{Methods}

\section{Data collection}

Household surveys and focus group discussions were conducted during November-December 2014. Of the 775 households in the Garjyangkot Village Development Committee, members of 65 households were interviewed using a structured questionnaire adapted and modified from the prototype developed by the Poverty Environment Network (PEN, 2008). The questionnaire contained three sections: household characteristics (age, gender, qualification, profession, family size), economic characteristics (land holdings, sources of cash income, estimated earnings from various sources), and yarsagumba-related information (harvesting experiences, number of pieces harvested, price, earning and expenditure related to the selling of yarsagumba). The questions were prepared, and the interviews conducted, in Nepali. Only individuals $>18$ years of age, with at least
5 years of harvesting experience, and who had harvested yarsagumba in the survey year were interviewed. Respondents meeting these criteria were selected for interview by visiting a random sample of households. The research proposal was approved by a scientific committee at the Kathmandu Forestry College, Tribhuvan University, Nepal. The survey questionnaire was also approved by the Institutional Review Board of the University of Massachusetts, Boston, USA. Respondents were informed of the study objectives, and assured anonymity and confidentiality of their personal information, at the beginning of face-to-face interviews. Interviews proceeded only if respondents voluntarily provided verbal or written consent. Three of the 65 interviews were excluded from analysis because they were incomplete.

Focus group discussions and key informant interviews were also conducted with representatives of various sectors of the village (schoolteachers, local political leaders, government officials, residents) to identify harvesting trends and contribution of yarsagumba to their livelihoods, and to triangulate the responses derived from the household survey.

\section{Data analysis}

As the primary aim of the study was to measure the contribution of yarsagumba to the household cash income, we collected and analysed only the total cash or equivalent income of the household. The sources of cash income were grouped into five categories: agricultural (crop and livestock) and non-timber forest products, excluding yarsagumba; business; seasonal labour; service; and yarsagumba harvesting. Based on the total household cash income, excluding income from yarsagumba, the sample population was divided into the tertiles poorest (21), intermediate (20) and poor (21), and the validity was tested by comparing the means using one-way ANOVA. In terms of wealth status the respondents were mostly poor, and therefore we didn't use the terminology 'rich' to describe better-off households, as is widely done in the literature (e.g. Olsen \& Larsen, 2003). The difference in non-cash assets (land holdings, houses) among the respondents was minimal.

We calculated the proportion of expenditure of income from yarsagumba in various categories (medicine, food, savings, children's education, celebrating festivals, clothes, and others). We calculated decomposed Gini coefficients based on the cash income tertiles, and examined the Lorenz curve to measure the equalizing effect of yarsagumba income on the total household cash income. The Gini coefficient is a commonly used measure of income inequality (a value of zero denotes perfect income equality, with everyone having the same income, and a value of one denotes maximum inequality, with all income held by a single person; Worku et al., 2014; Nakakaawa et al., 2015). We also quantified the trends in harvesting in terms of per capita harvest and 
income from yarsagumba in the previous 5 years, using linear regression.

\section{Results}

\section{Demographic characteristics of respondents}

The demographic characteristics of the respondents are in Table 1. The majority (98.4\%) of respondents were male (although the number of females collecting yarsagumba has increased in recent years, $>90 \%$ of yarsagumba harvesters in the village are male). Females did not want to be interviewed, and were hesitant to speak with outsiders. The mean age of the respondents was 29 years. Almost half (46.8\%) of the sampled population had a mean household size of 6-10 members, and only $30.6 \%$ of households had food sufficiency for $>9$ months in a year. Almost one-third of the respondents were illiterate, and none had completed a bachelor's degree or higher. Farming was the major occupation in the study area, with $>85.4 \%$ of respondents indicating their primary occupation was subsistence farming. The mean land holding per household was 1.1 ha. Respondents had been harvesting yarsagumba for a mean of 7.4 years, and spent a mean of 35 days each year collecting yarsagumba.

\section{Contribution of income from yarsagumba to total household income}

Table 2 provides an overview of household cash income in three income tertiles: poorest, intermediate and poor. The mean total cash income of the surveyed households was USD 2,287.2 \pm SD 1,087.1 per year. Cash earnings from yarsagumba harvesting contributed $64.5 \%$ of the mean total cash income, followed by agriculture and non-timber forest products (17.1\%), seasonal labour (9.6\%), service (6.0\%) and business (2.8\%). The contribution of yarsagumba to the total household cash income differed significantly among the tertiles $(\mathrm{P}<0.000$, Posthoc Bonferroni-Holm $F=10.98)$; it contributed $85.7 \%$ of the income of the poorest households, $69.9 \%$ for intermediate households, and $38.3 \%$ for poor households. Only the poor households reported earnings from services and business, whereas the poorest and intermediate households relied solely on agriculture and nontimber forest products, seasonal labour, and yarsagumba harvesting for generating cash. Only seven respondents mentioned that they earned cash from doing business, and only six had employment in government or nongovernment organizations.

\section{Expenditure of yarsagumba income}

We categorized the reported expenditure of income from yarsagumba as medicine, food, savings, children's
TABLE 1 Demographic characteristics of the survey respondents in Garjyangkot village, Jumla district, Nepal (Fig. 1).

\begin{tabular}{|c|c|c|}
\hline Demographic characteristics & Number $\pm S D$ & $\%$ \\
\hline Total number of respondents & 62 & \\
\hline Male & 61 & 98.4 \\
\hline Female & 1 & 1.64 \\
\hline \multicolumn{3}{|l|}{ Family size } \\
\hline$<5$ members & 27 & 43.6 \\
\hline 6-10 members & 29 & 46.8 \\
\hline$>10$ members & 6 & 9.6 \\
\hline Age (years) & $29.3 \pm 10.6$ & \\
\hline \multicolumn{3}{|l|}{ No. of food-sufficient months per year } \\
\hline$<3$ & 3 & 4.8 \\
\hline $3-6$ & 19 & 30.6 \\
\hline $6-9$ & 21 & 33.9 \\
\hline$>9$ & 19 & 30.7 \\
\hline \multicolumn{3}{|l|}{ Academic qualification } \\
\hline Illiterate & 18 & 29.0 \\
\hline Literate (up to class 8 ) & 16 & 25.80 \\
\hline Secondary (class 9-12) & 28 & 45.2 \\
\hline Bachelor's degree or higher & 0 & 0.0 \\
\hline \multicolumn{3}{|l|}{ Profession } \\
\hline Farming & 53 & 85.5 \\
\hline Service & 6 & 9.7 \\
\hline Business & 3 & 4.8 \\
\hline Mean land ownership (ha) & $1.1 \pm 0.7$ & \\
\hline Harvesting experience (years) & $7.4 \pm 3.3$ & \\
\hline Mean time spent harvesting (days) & $35.0 \pm 12.1$ & \\
\hline
\end{tabular}

education, celebrating festivals, clothes, and other (e.g. electronics, travel, entertainment; Fig. 2). On average, the top three categories of expenditure were clothes (17\%), food (16\%) and celebrating festivals (14\%). Respondents saved $27 \%$ of total earnings from yarsagumba harvesting, and $>61 \%$ of respondents mentioned that they saved some of the money they earned from yarsagumba harvesting.

\section{Yarsagumba income and inequality}

We decomposed the contribution of yarsagumba income to the total Gini coefficient to investigate how this income contributed to overall income inequality. Excluding income from yarsagumba, the income inequality measured by the Gini coefficient was 0.58 . With the inclusion of yarsagumba income in the total household cash income, the Gini coefficient decreased to 0.36 , indicating the equalizing effect of yarsagumba income on income inequality. The addition of income from yarsagumba harvesting to the household cash income reduced income inequality by $38 \%$. Similar trends were observed among the poorest, intermediate and poor households (Fig. 3). Likewise, the addition of income from yarsagumba to the total cash income reduced the area between the line of equality and the Lorenz curve, which is another indicator of the equalizing effect of yarsagumba income on total income inequality (Fig. 4); the departure 
TABLE 2 Cash income from various sources, and the \% contribution to total household income, for poorest, intermediate and poor households surveyed in Garjyangkot village, Jumla district, Nepal (Fig. 1).

\begin{tabular}{lcrrr}
\hline & \multicolumn{3}{l}{$\begin{array}{l}\text { Cash income, USD (\% contribution to total } \\
\text { household income) }\end{array}$} \\
\cline { 2 - 4 } Income source & Poorest & Intermediate & Poor & Sample mean \\
\hline Agriculture \& non-timber forest products, excluding yarsagumba & $142(12.5)$ & $361(23.2)$ & $431(15.9)$ & $310(17.1)$ \\
Seasonal labour & $93(1.8)$ & $209(7.0)$ & $764(19.8)$ & $434(9.6)$ \\
Services & $0(0)$ & $0(0)$ & $3,500(17.8)$ & $3,500(6.0)$ \\
Business & $0(0)$ & $0(0)$ & $771(8.3)$ & $771(2.8)$ \\
Yarsagumba harvesting & $1,269(85.7)$ & $1,439(69.9)$ & $1,423(38.3)$ & $1,376(64.5)$ \\
Total & $1,428.6(100)$ & $1,903.8(100)$ & $3,511.0(100)$ & $6,392.1(100)$ \\
\hline
\end{tabular}

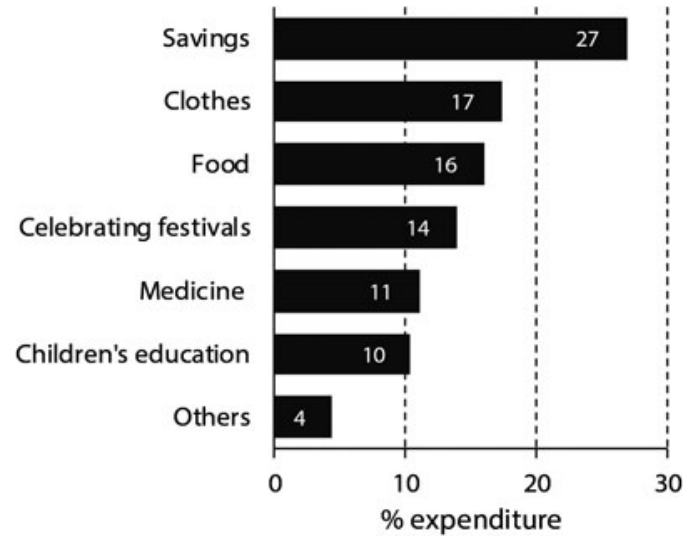

FIG. 2 Expenditure of income from the Chinese caterpillar fungus Ophiocordyceps sinensis (yarsagumba) by survey respondents from Garjyangkot village, Jumla district, Nepal (Fig. 1).

from the line of equality was greater when yarsagumba income was removed.

\section{Harvesting trends and their impact on household income}

According to our survey data the mean annual harvest per person was $347 \pm S D 251$ pieces, $(n=54)$ in 2010, and decreased to $229 \pm$ SD 181 pieces $(n=62)$ in 2014 (Fig. 5a). The mean annual decline during 2010-2014 was thus 25 pieces per harvester $(\mathrm{P}<0.003, F=8.64)$; however, the decline in harvesting did not affect the income from yarsagumba harvesting negatively. The mean earning of respondents was USD 604.12 \pm SD 505.8 in 2010, and had increased to $1,375.7 \pm$ SD 1,087.1 by 2014 (Fig. 5b), a significant increase of USD 194.1 per person per year $(\mathrm{P}<0.0001, F=36.84)$. During the same period the mean price of yarsagumba increased from USD 2 to USD 6 per piece, and the number of collectors at household level also increased (Fig. 6).

\section{Discussion}

Yarsagumba is a significant source of household cash income in the remote village of Jumla, Nepal. Among the

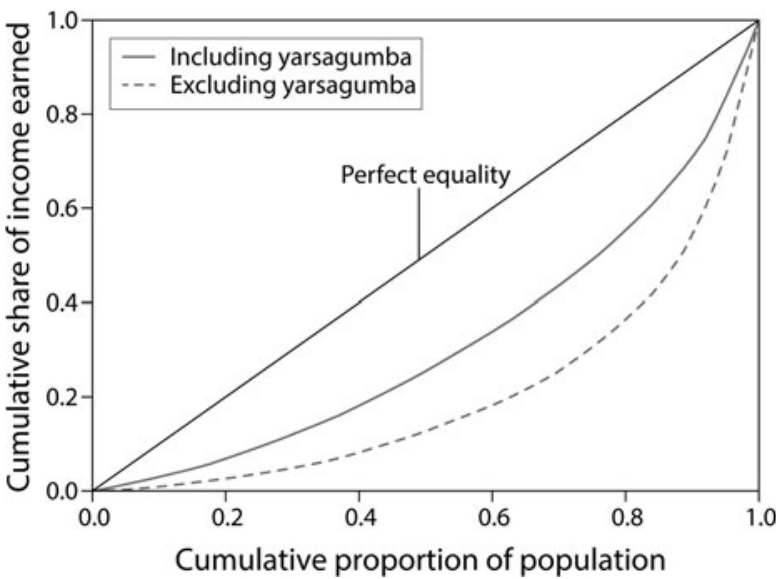

FIG. 3 Lorenz curve for household income including and excluding income from yarsagumba for surveyed households in Garjyangkot village, Jumla district, Nepal (Fig. 1).

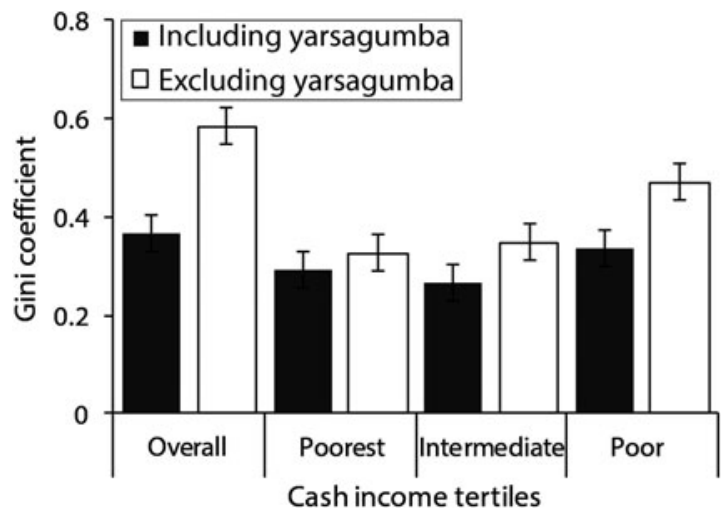

FIg. 4 Decomposed Gini coefficient by cash income tertiles for surveyed households in Garjyangkot village, Jumla district, Nepal (Fig. 1).

surveyed households it was the highest contributor (64.5\%) to the total household cash income, and has become an integral part of local livelihoods. This is comparable with the findings of other studies; yarsagumba was found to contribute $53.3 \%$ of total household income in rural households of Dolpa district, Nepal (Shrestha \& Bawa, 2014a), up to $72 \%$ 

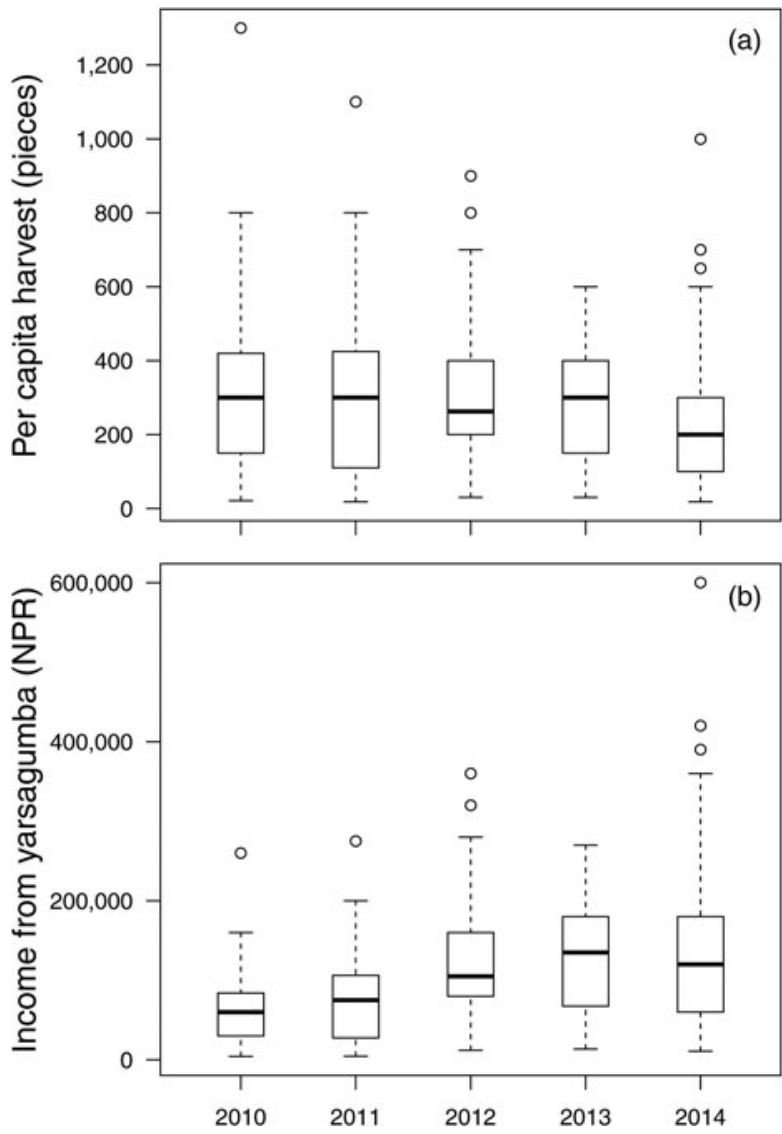

FIG. 5 Box-and-whisker plots of the temporal trend of (a) per capita harvesting of yarsagumba, and (b) the income derived from yarsagumba harvesting by surveyed households in Garjyangkot village, Jumla district, Nepal (Fig. 1) during 20102014. The horizontal line within the box indicates the median, the whiskers the maximum and minimum 1.5 interquartile ranges, and the dots outlying values.

in China (Woodhouse et al., 2014), up to $98 \%$ in India (Kuniyal \& Sundriyal, 2013), and up to $100 \%$ in Bhutan (Wangchuk et al., 2012). Discrepancies in reported values may be attributable to several factors, such as market price, methods used in monetization of the household income, sources of income of the local harvesters, and number of yarsagumba pieces collected by harvesters. For example, the higher contribution of income from yarsagumba in our study compared to that of Shrestha \& Bawa (2014a) may be attributable to an increase in the market price of yarsagumba. Likewise, the lower contribution of yarsagumba in this study compared to that of Woodhouse et al. (2014) may be because of the lower number of pieces harvested per capita (229 vs 404).

The proportion of total household cash income contributed by yarsagumba differed significantly among the cash income tertiles. Better-off households earned a substantial amount of cash from business and services, whereas the poorest households relied on yarsagumba collection, seasonal labour, farming and collection of non-timber forest

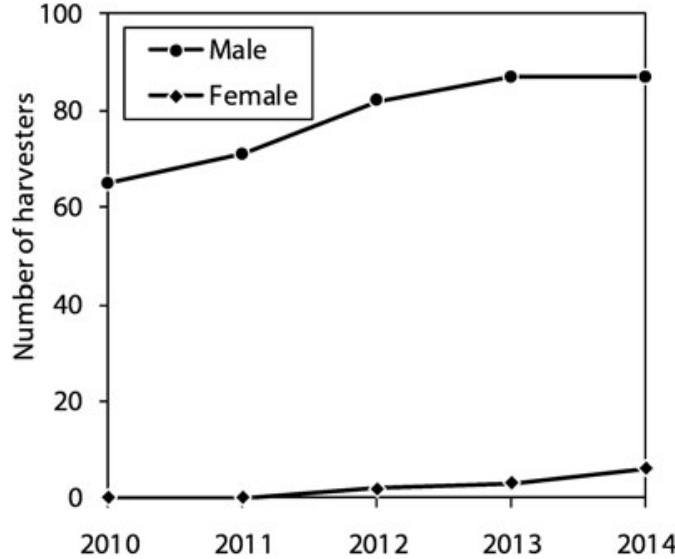

FIG. 6 Trends in the number of yarsagumba harvesters (male and female) in surveyed households in Garjyangkot village, Jumla district, Nepal (Fig. 1) during 2010-2014.

products. The higher reliance of the poorest households (which also have the lowest earnings from yarsagumba) on the income derived from yarsagumba harvesting indicates that the consequences of resource degradation will be severe for households that are already poor. Our finding of high dependence of the poorest households confirms the finding of Shrestha \& Bawa (2014a), also in Nepal, but contradicts that of Woodhouse et al. (2014) that in Tibet wealthier households have the highest dependency on yarsagumba. Woodhouse et al. (2014) reported that wealthier households in Sichuan Province, China, were larger than poorer households. In larger households there would be more people to collect yarsagumba, and thus increase the household income (Shrestha \& Bawa, 2014a). However, we did not find any correlation between wealth status and family size. The decline in the number of yarsagumba pieces harvested in Nepal has not resulted in reduced earnings, as the price has increased; however, there is no guarantee that the market price will continue to increase. If the market price drops or remains unchanged and the decline in per capita harvest continues, the consequences will be a reduced income for the poorest people.

Our finding regarding the decline in per capita harvest supports previous findings on resource decline (Shrestha \& Bawa, 2013; Shrestha et al., 2014). However, the decline in per capita harvest can be attributed to the steady increase in the number of collectors. Whereas the reported numbers of collectors in certain pastures of Dolpa were relatively stable (Shrestha \& Bawa, 2013), we found that the proportion of collectors at the household level has been increasing in Jumla; more members of the households collect yarsagumba now than previously. However, government revenue data indicate that the amount of yarsagumba collected in Jumla district declined during 2012-2014 (DFO, 2014). A similar decline has been reported elsewhere, and concern has been raised regarding the sustainability of the harvest 
(Cannon et al., 2009; Shrestha \& Bawa, 2013). However, the exact cause of the decline is yet to be determined. The reported decline could be a result of overharvesting, premature harvesting, a decrease in moth and larval populations, modification of the soil microhabitats congenial to fungal spores by the harvesters, increased grazing intensity, or climate change (Shrestha \& Bawa, 2013). Whatever the cause may be, if the recent decline at per capita level continues and the price does not increase, there will be serious consequences for the livelihoods of these poor mountain communities.

Regarding the expenditure of income from yarsagumba, we found that the largest proportion of the income was used for savings, followed by food and clothes, and children's education, thus helping to reduce poverty (Belcher, 2005). The study area has a high level of poverty and income inequality. The income inequality as measured in Gini coefficient in the study area (0.58) was higher than that national mean of 0.40 (UNDP, 2015) Both the reduction in Gini coefficient value and the Lorenz curve indicated the equalizing effect of income from yarsagumba. Other studies in Nepal (Rayamajhi et al., 2012; Chhetri et al., 2015; Walelign et al., 2016) and elsewhere (Vedeld, 2004) have also shown that the inclusion of environmental income has an equalizing effect on income inequality. In Jumla district poverty and inequality are higher than the national mean, and the food security situation has been worse historically (GoN, 2015). Income from yarsagumba has been helping poor people improve their standard of living but a more detailed longitudinal study would be needed to investigate this further.

This work has two limitations. Firstly, we did not include sources of subsistence income, and incorporate only the reported sources of cash income. This may not have had a significant impact on the overall results, as our objective was to evaluate the contribution of yarsagumba to household cash income. However, care should be taken in making comparisons with other studies that report only the total household income. Secondly, we did not assess the effects of socioeconomic factors (age, education level, family size and others) on the relative income of the households, as has been done in similar studies on the contribution of environmental income to rural households (e.g. Mamo et al., 2007; Vedeld et al., 2007; Worku et al., 2014). However, in the case of yarsagumba, entire villages are involved in harvesting, regardless of age, gender, income and other socio-economic characteristics, and a previous study found that socioeconomic characteristics (education level of the harvesters, age, and family size) had no effect on income from yarsagumba (Shrestha \& Bawa, 2014a).

Our findings indicate the importance of yarsagumba as a resource for local communities in regions where agricultural productivity is limited and there are few sources of livelihood opportunities. However, increasing dependence on yarsagumba will leave these communities vulnerable if yarsagumba continues to decline. Furthermore, these areas have already been affected by climate change, and future climate change is likely to have a negative effect on yarsagumba (Shrestha et al., 2012; Shrestha \& Bawa, 2014b).

The ecological impacts of yarsagumba harvesting, such as loss of pasture as a result of trampling, soil compaction, deforestation, and dumping of solid waste in the pastures, pose a threat to the environmental health of yarsagumba habitats (Shrestha et al., 2014). Sustainable management of yarsagumba and its habitats is therefore essential. However, it is not yet clear how yarsagumba can be managed sustainably, and what interventions are effective. Sustainable management is further complicated by poor understanding of the life cycle and propagation methods of the fungus, and of lesser-known impacts of interventions such as rotational harvesting. More research is needed, particularly on ecological and institutional aspects of resource management (e.g. access and management rules, ownership of the yarsagumba habitat, enforcement of rules, conflict resolution mechanisms) of yarsagumba, to inform a strategy for its long-term conservation.

\section{Acknowledgements}

We thank Bharat Gotame, Naresh Bhandari, Ek Raj Budha and the people of Garjyankot Village Development Committee for their support, and the local village authority for permission to conduct field research. We also acknowledge the Rufford Foundation, UK, for financial support to Uttam Babu Shrestha.

\section{Author contributions}

UBS co-designed the study and analysed the data. KRD collected the data. APG co-designed the study. All authors contributed to writing the article.

\section{References}

Agency (2016) Half animal-half plant herb harvest denudes Tibetan plains China Dialogue. Http://www.star2.com/living/livingenvironment/2016/02/10/harvesting-half-animal-half-plantdenudes-tibetan-plains/ [accessed 12 February 2016].

Angelsen, A. \& Wunder, S. (2003) Exploring the Forest-Poverty Link: Key Concepts, Issues and Research Implications. CIFOR Occasional Paper no. 40. CIFOR, Bogor, Indonesia.

Angelsen, A., JAgger, P., Babigumira, R., Belcher, B., Hogarth, N.J., B AUCH, S. et al. (2014) Environmental income and rural livelihoods: a global-comparative analysis. World Development, 64, S12-S28.

BeLCHER, B.M. (2005) Forest product markets, forests and poverty reduction. International Forestry Review, 7, 82-89.

Béné, C., Steel, E., Luadia, B.K. \& Gordon, A. (2009) Fish as the "bank in the water" - evidence from chronic-poor communities in Congo. Food Policy, 34, 108-118. 
Cannon, P.F., Hywel-Jones, N.L., Maczey, N., Norbu, L., Tshitila, Samdup, T. \& Lhendup, P. (2009) Steps towards sustainable harvest of Ophiocordyceps sinensis in Bhutan. Biodiversity and Conservation, 18, 2263-2281.

CBS (Central Bureau of Statistics) (2015) Annual Household Survey 2014/15. Major Findings. Government of Nepal, National Planning Commission Secretariat, Central Bureau of Statistics, Kathmandu, Nepal.

Chhetri, B.B.K., Larsen, H.O. \& Smith-Hall, C. (2015) Environmental resources reduce income inequality and the prevalence, depth and severity of poverty in rural Nepal. Environment, Development and Sustainability, 17, 513-530.

Childs, G. \& Choedup, N. (2014) Indigenous management strategies and socioeconomic impacts of Yartsa Gunbu (Ophiocordyceps sinensis) harvesting in Nubri and Tsum, Nepal. Himalaya, 34, 7.

DPR (Department of Plant Resources) (2014) Proceedings of the National Workshop on Conservation and Management of Yarsagumba. Department of Plant Resources, Ministry of Forests and Soil Conservation, Kathmandu, Nepal.

DFO (District Forest Office) (2014) Revenue Records of the Non-Timber Forest Products (NTFPs) Traded in Jumla. District Forest Office, Jumla, Nepal. [In Nepali]

GoN (Government of Nepal) (2004) Herbs and Non-timber Forest Product Development Policy. Department of Plant Resources, Kathmandu, Nepal. [In Nepali]

GoN (Government of Nepal) (2015) District Profile of Jumla, Government of Nepal. Ministry of Agricultural Development, Kathmandu, Nepal.

Heinen, J.T. \& Shrestha-Acharya, R. (2011) The non-timber forest products sector in Nepal: emerging policy issues in plant conservation and utilization for sustainable development. Journal of Sustainable Forestry, 30, 543-563.

Kuniyal, C.P. \& Sundriyal, R.C. (2013) Conservation salvage of Cordyceps sinensis collection in the Himalayan mountains is neglected. Ecosystem Services, 3, e40-e43.

Mamo, G., Sjaastad, E. \& Vedeld, P. (2007) Economic dependence on forest resources: a case from Dendi District, Ethiopia. Forest Policy and Economics, 9, 916-927.

Meilby, H., Smith-Hall, C., Byg, A., Larsen, H.O., Nielsen, Ø.J., PuRi, L. \& Rayamajhi, S. (2014) Are forest incomes sustainable? Firewood and timber extraction and productivity in community managed forests in Nepal. World Development, 64, S113-S124.

Nakakaawa, C., Moll, R., Vedeld, P., Sjaastad, E. \& Cavanagh, J. (2015) Collaborative resource management and rural livelihoods around protected areas: a case study of Mount Elgon National Park, Uganda. Forest Policy and Economics, 57, 1-11.

Nepal National Planning Commission (2003) The Tenth Plan (Poverty Reduction Strategy Paper) 2002-2007: Summary. Kathmandu, Nepal.

Nepal Rastra Bank (2015) Impact of Yarsagumba on Nepalese Economy. Study report. Investigation Department, Nepal Rastra Bank, Kathmandu, Nepal.

OKSANEN, T. \& MeRSMANN, C. (2003) Forests in poverty reduction strategies: an assessment of PRSP processes in Sub-Saharan Africa. Forests in Poverty Reduction Strategies: Capturing the Potential. EFI Proceedings, 47, 121-158.

Olsen, S.C. \& Larsen, O.H. (2003) Alpine medicinal plant trade and Himalayan mountain livelihood strategies. The Geographical Journal, 169, 243-254.

Pant, B., Rai, R., Wallrapp, C., Ghate, R., Shrestha, U. \& Ram, A. (2017) Horizontal integration of multiple institutions: solutions for Yarshagumba related conflict in the Himalayan region of Nepal? International Journal of the Commons, 11, 464-486.
Pen (Poverty Environment Network) (2008) PEN prototype questionnaire, version 4.4. Http://www.cifor.org/pen/the-penprototype-questionnaire/ [accessed 2 March 2012].

Pouliot, M. \& Treue, T. (2013) Rural people's reliance on forests and the non-forest environment in West Africa: evidence from Ghana and Burkina Faso. World Development, 43, 180-193.

Rayamajhi, S., Smith-Hall, C. \& Helles, F. (2012) Empirical evidence of the economic importance of Central Himalayan forests to rural households. Forest Policy and Economics, 20, 25-35.

Roe, D. (2010) Linking biodiversity conservation and poverty alleviation: a state of knowledge review. CBD Technical Series No. 55 .

Roe, D., Fancourt, M. \& Sandbrook, C. (2015) Biodiversity Conservation and Poverty Reduction: What's the Connection? A Systematic Mapping of the Evidence. IIED Research Report, London, UK.

Sachs, J.D., Baillie, J.E.M., Sutherland, W.J., Armsworth, P.R., Ash, N., Beddington, J. et al. (2009) Biodiversity conservation and the Millennium Development Goals. Science, 325, 1502-1503.

Saha, D. \& Sundriyal, R.C. (2012) Utilization of non-timber forest products in humid tropics: implications for management and livelihood. Forest Policy and Economics, 14, 28-40.

Shackleton, C. \& Shackleton, S. (2004) The importance of non-timber forest products in rural livelihood security and as safety nets: a review of evidence from South Africa. South African Journal of Science, 100, 658-664.

Shackleton, C.M. \& Pandey, A.K. (2014) Positioning non-timber forest products on the development agenda. Forest Policy and Economics, 38, 1-7.

Sharma, P., Guha-Khasnobis, B. \& Raj Khanal, D. (2014) Nepal Human Development Report 2014. Government of Nepal and United Nations Development Programme, Kathmandu, Nepal.

Shrestha, U.B. \& BAwa, K.S. (2013) Trade, harvest, and conservation of caterpillar fungus (Ophiocordyceps sinensis) in the Himalayas. Biological Conservation, 159, 514-520.

Shrestha, U.B. \& Bawa, K.S. (2014a) Economic contribution of Chinese caterpillar fungus to the livelihoods of mountain communities in Nepal. Biological Conservation, 177, 194-202.

Shrestha, U.B. \& BAwA, K.S. (2014b) Impact of climate change on potential distribution of Chinese caterpillar fungus (Ophiocordyceps sinensis) in Nepal Himalaya. PLoS ONE, 9(9), e106405.

Shrestha, U.B., Gautam, S. \& BAWA, K.S. (2012) Widespread climate change in the Himalayas and associated changes in local ecosystems. PLoS ONE, 7(5), e36741.

Shrestha, U.B., Shrestha, S., Ghimire, S., Nepali, K. \& Shrestha, B.B. (2014) Chasing Chinese caterpillar fungus (Ophiocordyceps sinensis) harvesters in the Himalayas: harvesting practice and its conservation implications in western Nepal. Society \& Natural Resources, 27, 1242-1256.

Sunderlin, W.D., Angelsen, A., Belcher, B., Burgers, P., Nasi, R., SAntoso, L. \& Wunder, S. (2005) Livelihoods, forests, and conservation in developing countries: an overview. World Development, 33, 1383-1402.

Thapa, B.B., Panthi, S., Rai, R.K., Shrestha, U.B., Aryal, A., Shrestha, S. \& Shrestha, B. (2014) An assessment of yarsagumba (Ophiocordyceps sinensis) collection in Dhorpatan hunting reserve, Nepal. Journal of Mountain Science, 11, 555-562.

Turner, W.R., Brandon, K., Brooks, T.M., Gascon, C., Gibbs, H. K., LAWRENCE, K.S. et al. (2012) Global biodiversity conservation and the alleviation of poverty. BioScience, 62, 85-92.

UndP (United Nations Development Programme) (2015) Human Development Report. United Nations Development Programme, New York, USA.

Vedeld, P. (2004) Counting on the Environment: Forest Incomes and the Rural Poor. Environmental Economics Series No. 98. 
International Bank for Reconstruction and Development, Washington, DC, USA.

Vedeld, P., Angelsen, A., Bojo, J., Sjaastad, E. \& Berg, G.K. (2007) Forest environmental incomes and the rural poor. Forest Policy and Economics, 9, 869-879.

Walelign, S.Z., Charlery, L., Smith-Hall, C., Chhetri, B.B.K. \& Larsen, H.O. (2016) Environmental income improves household-level poverty assessments and dynamics. Forest Policy and Economics, 71, 23-35.

Wangchuk, S., Norbu, N. \& Sherub, N. (2012) Impacts of Cordyceps Collection on Livelihoods and Alpine Ecosystems in Bhutan as Ascertained from Questionnaire Survey of Cordyceps Collectors. Royal Government of Bhutan, UWICE Press, Bumthang, Bhutan.

Winkler, D. (2009) Caterpillar fungus (Ophiocordyceps sinensis) production and sustainability on the Tibetan Plateau and in the Himalayas. Asian Medicine, 5, 291-316.

Woodhouse, E., McGowan, P. \& Milner-Gulland, E.J. (2014) Fungal gold and firewood on the Tibetan plateau: examining access to diverse ecosystem provisioning services within a rural community. Oryx, 48, 30-38.

Worku, A., Pretzsch, J., Kassa, H. \& Auch, E. (2014) The significance of dry forest income for livelihood resilience: the case of the pastoralists and agro-pastoralists in the drylands of southeastern Ethiopia. Forest Policy and Economics, 41, 51-59.
World Bank (2004) Sustaining Forests: A Development Strategy. World Bank, Washington, DC, USA.

Wunder, S., Angelsen, A. \&Belcher, B. (2014) Forests, livelihoods, and conservation: broadening the empirical base. World Development, 64, $\mathrm{S}_{1-S_{11}}$.

Wynberg, R., Laird, S., Van Niekerk, J. \& Kozanayi, W. (2015) Formalization of the natural product trade in southern Africa: unintended consequences and policy blurring in biotrade and bioprospecting. Society \& Natural Resources, 28, 559-574.

Zhou, X., Gong, Z., Su, Y., Lin, J. \& TAnG, K. (2009) Cordyceps fungi: natural products, pharmacological functions and developmental products. Journal of Pharmacy and Pharmacology, 61, 279-291.

\section{Biographical sketches}

Uttam Babu Shrestha's research interests focus on natural resource management, quantification and mapping of ecosystem services, and ecological responses to climate change. KRISHNA RAM DH IT AL's research interests include community forestry, non-timber forest products and natural resource management. AMBIKA PRASAD GAUTAM's research interests include community forestry, natural resource management, ecosystem services and biodiversity. 